\title{
Aeromonas species research in samples of water and beef obtained at industrial level
}

\section{Pesquisa de espécies de Aeromonas em amostras de água e carne bovina obtidas em nível industrial}

\author{
Oswaldo Durival Rossi Júnior', lacir Francisco dos Santos², Luiz Augusto do Amaral², \\ Andrea Magalhães Barbosa²
}

\begin{abstract}
The presence of bacteria of the genus Aeromonas in food of animal origin has been demonstrated by several authors. Among the most often cited foods are those which, during their preparation, come into contact with water which is considered to be the habitat of different species and the major source of food contamination. Thus, in order to determine the occurrence of bacteria of the genus Aeromonas in an abattoir where cattle is slaughtered and beef is processed, 20 samples of the water supply, 20 samples of residual water from carcass washing, and 20 samples of meat, were analyzed. The results showed the occurrence of aeromonads in $40 \%$ of the samples of residual water from carcass washing, represented only by the species $A$. caviae, and in $25 \%$ of the meat samples (A. hydrophila in $15 \%$ and $A$. caviae in $10 \%$ ). The fact that no aeromonads were isolated from the water supply samples suggests the existence of other sources of beef contamination.
\end{abstract}

Key words: Aeromonas; water supply; residual water; beef

\section{Introduction}

The genus Aeromonas belongs to the family Vibrionaceae and is subdivided into two groups based on characteristics of motility and temperature requirements. The non-mobile and psycrophilic group consists of a single species, $A$. salmonicida, with the subspecies salmonicida, achromogenes, and masoucida; the mobile and mesophilic group comprises three species: A. hydrophilla, A. caviae and $A$. sobria, being the first of them the type species (Popoff, 1984).

According to Majjed et al. (1990), in the United States food-poisoning diseases are responsible for large economic losses, especially because of lost working hours. Buchanan (1984) pointed out that 35 to $40 \%$ of the cases recorded each year are of unknown origin, many of them being provoked by bacterial species not routinely determined during the investigation of outbreaks. Among these bacteria are the mobile aeromonads (Gracey et al., 1982; Janda et al., 1983; Abeyta Junior et al., 1986).

Mobile aeromonads are microorganisms widely diffused in the environment (Cunliffe \& Adcock, 1989) and are important members of the normal microbiota of water (Pathak et al., 1988), having been isolated from polluted waters (Nygard et al., 1970), from unchlorinated waters (Burke et al., 1984) and also from chlorinated water (LeChevallier et al., 1982).

Concerning to pathogenicity, some mobile aeromonads are pathogenic to man and animals. The species $A$. hydrophila is known to be pathogenic to amphibians (DeFigueiredo \& Plumb, 1977), reptiles (Shotts Junior et al., 1972) and fish (Haley et al., 1967) to which it causes mainly hemorrhagic septicemia, and to cattle, to which it causes abortion (Wohlegemuth et al., 1972). In humans, they cause gastroenteric diseases (Knochel, 1989) as well as nonintestinal diseases such as meningitis (Ellison \& Mostow, 1984), arthritis (Dean \& Post, 1967), endocarditis (Davis et al., 1978), osteomyelitis (Lopez et al., 1968) and peritonitis (Janda et al., 1983).

Most of the studies performed on the ecology of the gastroenterites caused by aeromonads have been concerned with establishing water as the major vehicle of transmission (Moyer, 1987; Neves et al., 1990). However, Buchanan and Palumbo (1985) consider aeromonads to be potential food poisoning species. In this respect, Callister and Agger (1987) consider water to be one of the most important sources of food contamination.

The objective of the present study was to determine the occurrence of aeromonad species at an abattoir where cattle is slaughtered and beef is processed, by the analysis of the water supply, residual water from carcass washing, and meat in order to verify the role of water as a possible source of contamination. 


\section{Material and Methods}

Samples of the water supply were collected with proper care to maintain asepsis (Apha, 1985), in amounts of 400 $\mathrm{ml}$ at one site in the slaughter room. To neutralize the action of chlorine were added $10 \%$ sodium thiosulfate to each sample at the rate of $0.1 \mathrm{ml} / 100 \mathrm{ml}$ water. The amount of residual chlorine was determined at the time of collection using the comparing disk for chlorine and $0.1 \%$ orthotoluidine as reagent (Cetesb, 1973).

Samples of residual water from carcass washing were collected during the stage in which the water runs along the outer and inner surfaces of half carcasses. These samples, each consisting of approximately $400 \mathrm{ml}$ of water corresponding to an average of 14 half carcasses, were collected into sterilized Erlenmeyer flasks.

The meat samples consisted of fragments removed from the neck (bleeding region) at the time when half carcasses were dressed, placed on Petri dishes and carried to the laboratory in styrofoam boxes containing ice cubes together with the water samples. Twenty samples from each collection site were analyzed.

Sample preparation and selective enrichment - The water samples were filtered through cellulose ester membranes. These membranes, which retained the filtrate, were cut into small fragments and the fragments were placed in $250 \mathrm{ml}$ of trypticase-soy broth (TSB) supplemented with ampicillin (Abeyta Junior et al., 1990). Selective enrichment of the meat samples was performed by homogeneizing $25 \mathrm{~g}$ of the sample with $225 \mathrm{ml}$ TSB and incubating in a BOD oven at $28^{\circ} \mathrm{C}$ for $24 \mathrm{hr}$.

Selective plating and presumptive identification of the genus - The enrichment cultures were inoculated into phenol red-starch-ampicillin agar (Palumbo et al., 1985) and into dextrin-ampicillin agar (Havelaar \& Vonk, 1988). After incubation at $28^{\circ} \mathrm{C}$ for $24 \mathrm{hr}$, six colonies suggestive of the genus, i.e., of a yellowish color and surrounded by an hydrolysis halo, were submitted to the oxidase, O/F glucose and catalase tests and to the test of resistance to the vibriostatic agent $\mathrm{O} / 129$ according to the procedure proposed by Popoff (1984) and Knochel (1990).

Species characterization - Species characterization was performed by the method of Popoff (1984), and using some other tests recommended by Abeyta Junior et al. (1990), such as motility, indole production, esculin and arginine hydrolysis, lysine and ornithine decarboxylation, acid production from inositol, salicin, sucrose, mannitol and arabinose fermentation, acetoin, sulfhydric gas and gas production from glucose, and growth at $37^{\circ} \mathrm{C}$.

\section{Results and Discussion}

Table shows that no viable aeromonads were detected in the water supply samples used at the abattoir. Although there are reports of the isolation of aeromonads from chlorinated water (LeChevallier et al., 1982; Burke et al., 1984), the level of $1.3 \mathrm{ppm}$ active chlorine present in the water analyzed, which corresponds to hyperchlorinated water, may be the limiting factor in the survival and development of the genus Aeromonas.

Table also shows that 8 of the 20 samples of residual water from carcass washing (40\%) were contaminated with bacteria of the genus Aeromonas.

Table - Number and percentage of positive samples and species of Aeromonas identified from supply water, residual water carcass washing and beef, obtained at industrial level

\begin{tabular}{lccl}
\hline Samples & $\begin{array}{c}\text { Total number } \\
\text { analyzed }\end{array}$ & $\begin{array}{c}\text { Positive } \\
\text { samples }\end{array}$ & Species \\
\hline $\begin{array}{l}\text { Water supply } \\
\text { Water from }\end{array}$ & 20 & $0(0)^{\star}$ & \\
carcasses washing & 20 & $8(40)$ & $\begin{array}{l}\text { A. caviae }(40)^{*} \\
\text { Meat }\end{array}$ \\
\hline Total & 20 & $5(25)$ & $\begin{array}{l}\text { A. hydrophila (15) } \\
\text { A. caviae (10) }\end{array}$ \\
\hline
\end{tabular}

* percent positive samples

Of the 20 meat samples analyzed, 5 (25\%) were contaminated (Table). An identical result was obtained by Knochel and Jeppesen (1990) when they analyzed chopped beef acquired commercially in Copenhagen, Denmark. However, Ibrahim and Mac Rae (1991) obtained higher rates of contamination (60\%) for meat samples acquired in Brisbane, Australia.

The presence of bacteria of the genus Aeromonas in residual water from carcass washing and in meat still inside the abattoir and the elimination of industrial water as the source of the bacteria suggest the existence of other sources of contamination. On this basis, water may no longer be, in a direct form, the most important source of contamination of food of animal origin at the industrial level, as established by Callister and Agger (1987) for foodstuffs in general. Drazek et al. (1986), after detecting a low incidence of aeromonads in cattle, swine and fowl feces, concluded that the manipulation of food may be an important source of contamination.

The data presented in Table, also related the isolation of aeromonad species from the residual water from carcass washing and from meat demonstrate that only the species $A$. caviae occurred in the former, whereas $A$. caviae and $A$. hydrophila were isolated from the latter, with a predominance of the second species.

The isolation of $A$. hydrophila from significantly higher percentages of samples compared to $A$. caviae and $A$. sobria has also been noted by Majjed et al. (1989) when analyzing lamb meat, by Knochel and Jeppesen (1990) when analyzing different types of foods of both animal and plant origin, by Ibrahim and Mac Rae (1991) when analyzing beef and milk, and by Okrend et al. (1987) when analyzing beef; pork and fowl meat. Several authors have char- 
acterized $A$. hydrophila as the species presenting the highest potential for pathogenicity (Pathak et al., 1988; Majjed et al., 1989; Cunliffe \& Adcock, 1989) and most frequently involved in human infections (Ellison et al., 1984; Abeyta Junior et al., 1986). These data demonstrate the importance of bacteria of the genus Aeromonas as potential food poisoning species; so, their isolation from food of animal origin should not be ignored by public health services.

Moyer (1987), in a study of the clinical significance of aeromonad species isolated from patients with diarrhea, concluded that strains of $A$. hydrophila, $A$. sobria and some strains of $A$. caviae can cause diarrhea and that antibiotic treatment and the ingestion of untreated water are significant risk factors for susceptible hosts. The present findings and those reported in the literature about the presence of Aeromonas in food allow us to add also food of animal origin as a risk factor for the transmission of the microorganisms to man according to the factors mentioned by Moyer (1987).

\section{Resumo}

\section{Pesquisa de espécies de Aeromonasem amostras de água e carne bovina obtidas em nível industrial}

A presença de bactérias do gênero Aeromonas em alimentos de origem animal tem sido demonstrada por diversos autores. Dentre os alimentos mais citados têm destaque aqueles que durante sua obtenção ou preparação entram em contato com a água, que é tida como habitat das diferentes espécies e principal fonte de contaminação para os alimentos. Assim, com o objetivo de verificar a ocorrência de bactérias do gênero Aeromonas em um estabelecimento que abate e industrializa carne bovina, foram analisadas 20 amostras de água de abastecimento, 20 de água residuária da lavagem de carcaças e 20 de carne. Os resultados obtidos mostraram a ocorrência de Aeromonas em $40 \%$ das amostras de água residuária da lavagem de carcaças, representados unicamente pela espécie $A$. caviae e em $25 \%$ das amostras de carne, sendo que em $15 \%$ delas esteve presente a $A$. hydrophila e em $10 \%$ a $A$. caviae. O não isolamento a partir das amostras de água de abastecimento sugere a existência de outras fontes de contaminação para a carne bovina.

Palavras chave: Aeromonas; água de abastecimento; água residuária; carne bovina

\section{Bibliographic references}

APHA - AMERICAN PUBLIC HEALTH ASSOCIATION. Standard methods for the examination of water and wastewater. 16th ed. New York, 1985.

ABEYTA JÚNIOR, C., KAYSNER, C.A., WEKEL, M.M., SULLIVAN, J.J., STEMA, G.N. Recovery of Aeromonas hydrophila from oysters implicated in an outbreak of foodborne illness. J. Food Prot., v. 49, p. 643-46, 1986.

ABEYTA JÚNIOR, C., KAYSNER, C.A., WEKELL, M.M., STOFF,
R.F. Incidence of motile aeromonads from United States west coast shellfish growing estuaries. J. Food Prot., v. 53, n.10, p. 849-55, 1990.

BUCHANAN, R.L. The "new" pathogens: an update of selected examples. Assoc. Food Drug Off. Q. Bull., v. 48, p. 142-55, 1984.

BUCHANAN, R.L., PALUMBO, S.A. Aeromonas hydrophila and Aeromonas sobria as potential food poisoning species: a review. J. Food Safety, v. 7, p. 15-29, 1985.

BURKE, V., ROBINSON, J., GRACEY, M., PETERSON, D., MEYER, N., HALEY, V. Isolation of Aeromonas spp. from an unchlorinated domestic water supply. Appl. Environ. Microbiol., v. 48, p. 367-70, 1984.

CALLISTER, S.M., AGGER, W.A. Enumeration and characterization of Aeromonas hydrophila and Aeromonas caviae isolated from grocery store produce. Appl. Environ. Microbiol., v. 53, p. 249-53, 1987.

CETESB. Operação e manutenção de E.T.A., São Paulo. Secretaria dos Serviços de Obras Públicas, 1973.

CUNLIFFE, D.A., ADCOCK, P. Isolation of Aeromonas spp. from water by using anaerobic incubation. Appl. Environ. Microbiol., v. 55, n. 9, p. 2138-40, 1989.

DAVIS, W.A., KANE, J.C., GARAGUSI, V.F. Human Aeromonas infections: A review of the literature and a case report of endocarditis. Medicine, v. 57, p. 267-77, 1978.

DEAN, H.M., POST, R.M. Fatal infection with Aeromonas hydrophila in a patient with acute myelogenous leukemia. Ann. Intern. Med., v. 66, p. 1177-1179, 1967.

DeFIGUEIREDO, J., PLUMB, J.A. Virulence of different isolates of Aeromonas hydrophila in channel catfish. Aquaculture, v.11, p. 349-354, 1977.

DRAZEK, E.S., STERN, N.J., JOSEPH, S. Low incidence of Aeromonas sp. in livestock feces. Abstr. Annual Meeting Am. Soc. Microbiol., p. 246, 1986.

ELLISON, R.T., MOSTOW, S.R. Pyogenic meningitis manifesting during therapy for Aeromonas hydrophila sepsis. Arch. Inter. Med., v. 144, p. 2078-2079, 1984.

GRACEY, M., BURKE, V., ROBINSON, J. Aeromonas associated gastroenteritis. Lancet, v. 2, p. 1304-06, 1982.

HALEY, R., DAVIS, S.P., HYDE, J.M. Environmental stress and Aeromonas liquefaciens in American and threadfin shad mortalities. Prog. Fish Cult., v. 29, p. 193, 1967.

HAVELAAR, A.H., VONK, M. The preparation of ampicillin dextrin agar for the enumeration of Aeromonas in water. Letters Appl. Microbiol., v. 7, p. 169-71, 1988.

IBRAHIM, A., MAC RAE, I.C. Incidence of Aeromonas and Listeria spp. in red meat and milk samples in Brisbane, Australia. Intern. J. Food Microbiol., v. 12, p. 263-70, 1991.

JANDA, M.J., BOTTONE, E.J., REITANO, M. Aeromonas species in clinical microbiology: significance, epidemiology and speciation. Diag. Microb. Infect. Dis., v. 1, p. 221-23, 1983.

$\mathrm{KNOCHEL}, \mathrm{S}$. Effect of temperature on hemolysin production in Aeromonas spp. isolated from warm and cold environments. Intern. J. Food Microbiol., v. 9, n. 3, p. 225-35, 1989.

KNOCHEL, S. Growth characteristics of motile Aeromonas spp. isolated from different environments. Inter. J. Food Microbiol., v. 10, n. $3 / 4$, p. 235-44, 1990.

KNOCHEL, S., JEPPESEN, C. Distribution and characteristics of Aeromonas in food and drinking water in Denmark. Intern. J. Food Microbiol, v. 10, n. 3/4, p. 317-22, 1990. 
LeCHEVALLIER, M.W., EVANS, T.M., SEIDLER, R.J., DAILY, O.P., MORRELL, B.R., ROLLINS, D.M., JOSEPH, S.W. Aeromonas sobria in chlorinated drinking water supplies. Microbiol. Ecol., v. 8, p. 325-33, 1982.

LOPEZ, J.F., QUESADA, J., SAIED, A. Bacteremia and osteomyelitis due to Aeromonas hydrophila: A complication during the treatment of acute leukemia. Amer. J. Clin. Pathol., v. 50 , p. 587-91, 1968.

MAJJED, K.N., EGAN, A.F., MAC RAE, I.C. Enterotoxigenic aeromonads on retail lamb meat and offal. J. Appl. Bacteriol., v. 67 , p. 165-70, 1989.

MAJEED, K.N., EGAN, A.F., MAC RAE, I.C. Production of exotoxins by Aeromonas spp. at $5^{\circ} \mathrm{C}$. J. Appl. Bacteriol., v. 69, p. 332-37, 1990.

MOYER, N.P. Clinical significance of Aeromonas species isolated from patients with diarrhea. J. Clin. Microbiol., v.25, p. 2044-48, 1987.

NEVES, M.S., NUNES, M.P., RICCIARDI, I.D. Incidence of motile Aeromonas species in aquatic environments of Rio de Janeiro, Brasil. J. Food. Prot., v. 53, n.1, p. 78-80, 1990.

NYGARD, G.S., BISSETT, M.L., WOOD, R.M. Laboratory identification of aeromonads from man and other animals. Appl. Environ. Microbiol., v. 19, p. 618-20, 1970.
OKREND, A.J.G., ROSE, B.E., BENNETT, B. Incidence and toxigenicity of Aeromonas species in retail poultry, beef and pork. J. Food Prot., v. 50, n. 6, p. 509-13, 1987.

PALUMBO, S.A., MAXINO, F., WILLIAMS, A.C., BUCHANAN, R.L., THAYER, D.W. Starch-ampicillin agar for the quantitative detection of Aeromonas hydrophila. Appl. Environ. Microbiol., v. 50, p. 1027-30, 1985.

PATHAK, S.P., BHATTACHERJEE, J.W., KALRA, N., CHANDRA, S. Seasonal distribution of Aeromonas hydrophila in river water and isolation from river fish. J. Appl. Bacteriol., v. 65, p. 347-52, 1988.

POPOFF, M. Genus III. Aeromonas Kluyver and Van Niel. In: DRIEG NOEL R., Bergey's manual of systematic bacteriology. Baltimore. Williams and Wilkins, 1984. p. 545548.

SHOTTS JÚNIOR, E.B., GAINES, J.L., MARTIN, C., PRESTWOOD, A.K. Aeromonas induced deaths among fish and reptiles in an eutrophic inland lake. J. Am. Vet. Med. Assoc., v. 161, p. 603-7, 1972.

WOHLEGEMUTH, D., PIERCE, R.L., KIRKBRIDE; C.A. A bovine abortion association with Aeromonas hydrophila. J. Am. Vet. Assoc., v. 160, p. 1001-2, 1972. 